\title{
Improvements in geophysical surface soil assessment and classification using modifying Jenny's equation of soil forming factors in the Sudan Savannah
}

\author{
*S Usman ${ }^{1}$, PJA Burt ${ }^{1}$, A Aminu $^{1}$, SSNoma $^{2 *}$, I Hamisu $^{2 * *}$ and UG Lawal ${ }^{3}$ \\ ${ }^{I}$ Natural Resources Institute, Agriculture, Health and Environment Department, University of Greenwich at \\ Medway, Chatham Maritime, Chatham Kent ME7 4TB, United Kingdom \\ ${ }^{2 *}$ Department of Soil Science, Faculty of Agriculture; ${ }^{2 * *}$ Department of Geography, Faculty of Social \\ Science; UsmanDanfodiyo University Sokoto, Sokoto State Nigeria \\ ${ }^{3}$ Department of Geography, AdamuAugie Collage of Education Argungu, ArgunguKebbi State Nigeria
}

\begin{abstract}
Assessment and classification of agricultural surface soil in the Sudan Savannah, Kebbi State Nigeria was carried out from 2008 to 2011 using a modified version of Jenny's equation of soil forming factors. A comprehensive account of major classes of surface soil characteristics was given. The following surface soil components have been covered: temperature and moisture characteristics, topography, parent materials, organisms and land properties. Consequently, the physical agricultural surface soil conditions in five local government areas of the State: Arewa, Argungu, Augie, Birnin-Kebbi and Dandi are characterised by six major surface moisture characteristics: aquic, aridic, torric, udic, ustic and perudic; 10 topographical classes: backslope, bendy, concave, contour, convex, deeply,flatly, linear-flat and shallow; three major soil biota: ants, earthworms and termites; andseven land characteristics: bad-lands, blown-out-lands, cirque-lands, fertilelands, gulliedlands, miscellaneous and rock-outcrops. The major parent materials are alluvial, colluvial,fluvial and lacustrine. Physically, these parent materials are describe according to theirphysical appearance into fadama clay soils, fadama clay-loam soils, dryland sandy soils,dryland sandy-loam soils, dryland stony soils, and organic-mineral soils. Generally, the studyhas provided a better understanding of the current status of the major physical components ofagricultural soils and overall natural environment for future agricultural economic management in the region.
\end{abstract}

Keywords:VisualSoil Assessment, Soil forming factors, Soil classification

\section{Introduction}

Throughout the world history, many people have assessed and classified soils according to the purposes of its sustainability and suitability for agricultural activities in their localities (e.g. Soil Survey Staff, 1999). Similarly, in the Sudan Savannah (SS) farmers have classified soil according to the agricultural land use, given local names that are suitable to a particular area or crop or soil-colour. Some of these names as mentioned by farmers during the field visit in 2008 and 2010 are: Kasar-shinkafa (rice soil), Kasar-gero (millet soil), Fararkasa (white soil), Bakar-kasa (black soil), Jar-kasa (red soil), Rafi (valley area), Fadama (flood-plain areas), Tudu (dryland area), Laka (clay soil) and Yashi (sandy soil). However, because of the limitation of its uses in soil management (Usman, 2007), this farmer's classification of soils in the SS must be improved by scientific classification.Thisscientific classification of soil was reported to help in the establishment of hierarchies of surface soils classes, and permit the understanding of the relationship among soil components and the factors responsible for surface soils behaviour and surface soils formations and transformations (Soil Survey Staff, 2010).

It is well known that, soils are formed by an array of factors, namely: climate, organisms, parent material, relief and time (Jenny, 1994). This has been much cleared to soil scientists that, all soils result from the action of these five factors named after Jenny. Studies on soil forming factors are well documented in various aspect of soil science (physical, chemical, biological and ecological) (see Fitzpatrick, 1980; Olson, 1981; Harden, 1990; Phillip, 1992; Jenny, 1994; Goudie, 2001; Finch et al., 2002; Boulding and Jon, 2003; Certini, 2006; Usman, 2012), however, because of recent soil and environmental crises due to climate changes globally (e.g. IPCC, 2007), a further understanding of surface soils may be of great importance to agricultural development in the SS.

Factors of soil formation are considered as parent materials acted on by climate and organisms (microbes to elephants, including vegetation and man) as conditioned by relief over a period of time (Sundet al., 1973; Lal, 1998; Coleman, 2001; Lemke et al., 2003).The influence of these factors on physical nature and conditions of surface soils was best fully described by Jenny (1941, 1994). But soil must be understood according to Lal, (1998) not only as an immutable product of nature, even though sometime that is dynamic; 
constantly its physical aspect and dynamic conditions are equally important. Knowledge of the interaction and relationship of factors of soil formation is one of the key aspects to understand surface soil's condition (e.g. Boulding and Jon, 2003).

\subsection{Background of Jenney's equation of soil forming factors}

The soil forming factors that have been constituted in the Jenney's equation $[S=f(c l, o, r, p, t)]$ are: climate (cl), organism (o), relief (r), parent material (p) and time (t). According to Dokuchaev (1846-1903 quoted in Krasil'inikov (1961), soil can be describe as a natural body, having its own genesis and its own history of development, a body with complex and multiform processes, influencedbyclimate, relief, organisms, parent materials and time that control the degree of soil development (Harden, 1990; Jenny, 1994). These soil forming factors govern the geomorphic processes and landscape evolution in soil development (McFadden and Kneupfer, 1990). They are the result of most soils having a variety of particles such as sand, silt, clay and organic matter, which formed from the rock weathering and organic materials shaped by their transport in water and wind (Sundet al., 1973). Soil formation has been described by Jenny (1994) in his equation, as transformation of rock into soil (note: the rock may be gneiss, limestone, shale, sand, loess, peat, parent materials or soil material). In the initial stage, this transformation starts with parent material:

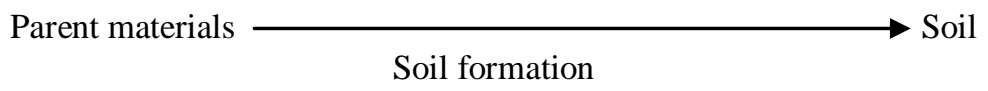

Time is an independent factor that controls the period taken to produce soil (Jenny, 1994; Brady and Weil, 2004). This means, a soil might form as a result of particles changing over a particular period of time, from the initial state to the mature state:

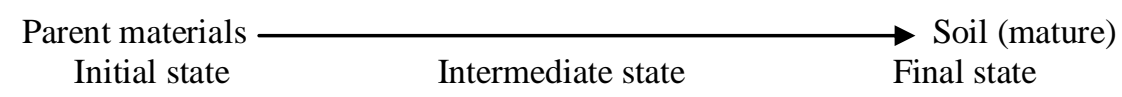

According to Finch et al. (2002), Lemke et al. (2003) and Certini (2006), soil can be treated as a dynamic system considering the above sequences. The emphasis here is placed on the changes of the properties of soil as a function of time (Jenny, 1994). As such, the two independent variables (parent materials and time) with other three variables: climate, organism and topography have been used to describe the whole system in soil formation (see Jenny, 1994; Goude, 2001; Finch et al., 2002; Boulding and Jon, 2003; Brady and Weil, 2004).

$$
S=F(C l+O+R+P+T) \quad E q .1
$$

Thus, it should be understand that (Brady and Weil, 2004): parent materials are soil particles of different shapes and sizes; climate determines the nature and intensity of the weathering that occurs over large geographic areas; organisms enhances the organic matter accumulation, biochemical weathering, profile mixing, nutrient cycling, and aggregate stability in surface and subsurface soils; topography relates to the configuration of the land surface and hasten or retard the work of climatic forces (rainfall intensity and wind speed); and time show their effects. In this regard, soils can be define as dynamic surface and subsurface components having particles called parent materials which were shaped and sized as a result of combine effects of climate, organisms, topography and time.

However, in the 1950s, 1960s, 1990s, and early 2000, soil scientists further clarified that human or anthropogenic factor is also part of soil formation (Bidwell and Hole, 1965; Yaalon and Yaron, 1966; Arnold et al., 1990; Amundson and Jenny, 1991; Dudalet al., 2002), and as such considered as one of the classical factor of soil formation (Dudal, 2004). From agricultural point of view, human activities have a great impact, since soil properties are often seriously changed by human intervention (Ritzema, 1994). Soil modified by human activities were often labelled as 'disturbed', 'artefacts', 'manipulated' or 'artificial' and considered to be 'deviation' rather than a part of the soil continuum (Dudal, 2004). And from soil science point of view, soil properties which may change over the human time scale in responses to anthropogenic factors (tillage, land use conservation, and farming) have been considered as dynamic soil properties (not a dynamic system of soil formation as mentioned earlier) (NRCS, 2004). In this regard, the Jenney's equation (Eq. 1) can be modified by adding $\mathrm{A}$ or anthropogenic factor, hence:

$$
S=f(C l+O+R+P+T) A \quad E q .2
$$

This concept of soil forming factors was used as theoretical background knowledge in modifying Jenney's equation to aid in the proper assessment and classification of surface soils in the SS. Therefore, the aim 
of this study was assessment and classification of surface soil using factors constituted in the modified Jenny's equation with specific objective to provide a field soil data report based on the current status of agricultural soils for the SS, Kebbi State Nigeria.

\subsection{Field Survey}

\section{Materials And Methods}

A field survey for detailed surface soil visualisation and assessment was carried out from 2008 to 2011 according to FAO guidelines for soil description (FAO, 2006) and soil visualisation (FAO, 2008). The survey area covered five Local Governments in Kebbi State Nigeria: Arewa, Argungu, AugieBirnin-Kebbi and Dandi. The region borders Niger Republic to the west and Benin Republic to the southwest. It is physically characterised by abundant dwarf and short-medium grasses of $1.7 \mathrm{~m}$ to $2.5 \mathrm{~m}$ and few scattered trees of different shapes, size and economic important. The total land area of the State including the SS is $36,229 \mathrm{~km}^{2}$ of which $12,600 \mathrm{~km}^{2}$ is under agriculture (KARDA, 1997). Seventy-four different surface soil areas were visited, assessed and visualised in the whole of the State's SS. The satellite images of these survey areas and their corresponding latitudes and longitudes are shown in Table 1 using Google earth geographer software (US Department of State Geographer, 2011).

Generally, the survey was performed by adapting the geomorphic surface soil approach (USDA-NRCS, 2002), a systematic method that helps to assess and collect adequate soil information by Visual Soil Assessment (VSA). VSA was defined as a direct evaluation of those soil properties which are visible by naked eye and which can be evaluated directly in the field (EU, 2010). The method was found profitable in assessing the key soil 'states', which are dynamic indicators capable of changing under different management regimes and landuse pressure (FAO, 2008). It is also included the description of surface soil characteristics, classification of surface soils according to a standard system of classification and predictions about the behaviour of soils according to its formation (Soil Survey Staff, 1999). However, during the visit, sites were selected according to surface land resources relevant to agricultural activities in the study area. The specific surface land resources considered are: cultivated lands, irrigated lands, grazing lands, rocks/gravels, scattered trees, and presence of crops or indication of farming activities.

Table 1: Latitude and Longitude directions of the survey sites in study area

\begin{tabular}{|c|c|c|c|c|c|c|c|c|c|}
\hline \multicolumn{2}{|c|}{$\begin{array}{l}\text { Arewa } \\
\text { Survey area No. 1-17 }\end{array}$} & \multicolumn{2}{|c|}{$\begin{array}{l}\text { Dandi } \\
\text { Survey area No. 18-31 }\end{array}$} & \multicolumn{2}{|c|}{$\begin{array}{l}\text { Augie } \\
\text { Survey area No. 32-44 }\end{array}$} & \multicolumn{2}{|c|}{$\begin{array}{l}\text { Argungu } \\
\text { Survey area No. } 45-60\end{array}$} & \multicolumn{2}{|c|}{$\begin{array}{l}\text { Birnin Kebbi } \\
\text { Survey area No. 61-74 }\end{array}$} \\
\hline Latitude & Longitude & Latitude & Longitude & Latitude & Longitude & Latitude & Longitude & Latitude & Longitude \\
\hline $12^{\circ} 44^{\prime} 41^{\prime \prime} \mathrm{N}$ & $4^{\circ} 17^{\prime} 12^{\prime \prime} \mathrm{E}$ & $11^{\circ} 50^{\prime} 50^{\prime \prime} \mathrm{N}$ & $3^{\circ} 44^{\prime} 12^{\prime \prime} \mathrm{E}$ & $12^{\circ} 48^{\prime} 59^{\prime \prime} \mathrm{N}$ & $4^{\circ} 29^{\prime} 52^{\prime \prime} \mathrm{E}$ & $12^{\circ} 34^{\prime} 41^{\prime \prime N}$ & $4^{\circ} 25^{\prime} 31^{\prime \prime} \mathrm{E}$ & $12^{\circ} 31^{\prime \prime} 54^{\prime \prime} \mathrm{N}$ & $4^{\circ} 23^{\prime} 45^{\prime \prime} \mathrm{E}$ \\
\hline $12^{\circ} 43^{\prime} 27^{\prime \prime} \mathrm{N}$ & $4^{\circ} 60^{\prime} 26^{\prime \prime} \mathrm{E}$ & $11^{\circ} 50^{\prime} 26^{\prime \prime N}$ & $3^{\circ} 44^{\prime} 22^{\prime \prime} \mathrm{E}$ & $12^{\circ} 49^{\prime} 00^{\prime \prime} \mathrm{N}$ & $4^{\circ} 30^{\prime} 27^{\prime \prime E}$ & $12^{\circ} 35^{\prime} 33^{\prime \prime N}$ & $4^{\circ} 25^{\prime} 41^{\prime \prime} \mathrm{E}$ & $12^{\circ} 32^{\prime} 11^{\prime \prime N}$ & $4^{\circ} 22^{\prime} 45^{\prime \prime E}$ \\
\hline $12^{\circ} 32^{\prime} 53^{\prime \prime N}$ & $3^{\circ} 55^{\prime} 59 " \mathrm{E}$ & $11^{\circ} 50^{\prime} 36^{\prime \prime} \mathrm{N}$ & $3^{\circ} 43^{\prime} 39^{\prime \prime} \mathrm{E}$ & $12^{\circ} 49^{\prime} 57^{\prime \prime N}$ & $4^{\circ} 31^{\prime} 12^{\prime \prime} \mathrm{E}$ & $12^{\circ} 36^{\prime} 27^{\prime \prime N}$ & $4^{\circ} 26^{\prime} 33^{\prime \prime} \mathrm{E}$ & $12^{\circ} 31^{\prime} 22^{\prime \prime} \mathrm{N}$ & $4^{\circ} 21^{\prime} 59^{\prime \prime E}$ \\
\hline $12^{\circ} 40^{\prime} 47^{\prime \prime N}$ & $4^{\circ} 30^{\prime} 55^{\prime \prime} \mathrm{E}$ & $11^{\circ} 50^{\prime} 37^{\prime \prime N}$ & $3^{\circ} 41^{\prime} 18^{\prime \prime} \mathrm{E}$ & $12^{\circ} 51^{\prime} 31^{\prime \prime N}$ & $4^{\circ} 32^{\prime} 41^{\prime \prime} \mathrm{E}$ & $12^{\circ} 37^{\prime} 23^{\prime \prime N}$ & $4^{\circ} 26^{\prime} 37^{\prime \prime} \mathrm{E}$ & $12^{\circ} 30^{\prime} 40^{\prime \prime} \mathrm{N}$ & $4^{\circ} 21^{\prime} 39^{\prime \prime E}$ \\
\hline $12^{\circ} 40^{\prime} 22^{\prime \prime} \mathrm{N}$ & $4^{\circ} 30^{\prime} 51$ "E & $11^{\circ} 51^{\prime} 91^{11 \mathrm{~N}}$ & $3^{\circ} 41^{\prime} 19 " \mathrm{E}$ & $12^{\circ} 51^{\prime} 13^{\prime \prime N}$ & $4^{\circ} 34^{\prime} 28^{\prime \prime E}$ & $12^{\circ} 37^{\prime} 30^{\prime \prime} \mathrm{N}$ & $4^{\circ} 27^{\prime} 24^{\prime \prime} \mathrm{E}$ & $12^{\circ} 30^{\prime} 52^{\prime \prime} \mathrm{N}$ & $4^{\circ} 20^{\prime} 42^{\prime \prime} \mathrm{E}$ \\
\hline $12^{\circ} 41^{\prime} 35^{\prime \prime N}$ & $4^{\circ} 50^{\prime} 19 " \mathrm{E}$ & $11^{\circ} 51^{\prime} 24^{\prime \prime N}$ & $3^{\circ} 40^{\prime} 24 " \mathrm{E}$ & $12^{\circ} 51^{\prime} 35^{\prime \prime N}$ & $4^{\circ} 35^{\prime} 11 " \mathrm{E}$ & $12^{\circ} 41^{\prime} 31^{\prime \prime N}$ & $4^{\circ} 30^{\prime} 70^{\prime \prime} \mathrm{E}$ & $12^{\circ} 31^{\prime} 90^{\prime \prime} \mathrm{N}$ & $4^{\circ} 20^{\prime} 16^{\prime \prime} \mathrm{E}$ \\
\hline $12^{\circ} 41^{\prime} 16^{\prime \prime} \mathrm{N}$ & $4^{\circ} 40^{\prime} 47^{\prime \prime} \mathrm{E}$ & $11^{\circ} 52^{\prime} 80^{\prime \prime} \mathrm{N}$ & $3^{\circ} 39^{\prime} 38^{\prime \prime} \mathrm{E}$ & $12^{\circ} 51^{\prime} 55^{\prime \prime N}$ & $4^{\circ} 37^{\prime} 55$ "E & $12^{\circ} 42^{\prime} 39^{\prime \prime} \mathrm{N}$ & $4^{\circ} 32^{\prime} 42^{\prime \prime} \mathrm{E}$ & $12^{\circ} 30^{\prime} 49^{\prime \prime} \mathrm{N}$ & $4^{\circ} 19^{\prime} 44^{\prime \prime E}$ \\
\hline $12^{\circ} 43^{\prime} 80^{\prime \prime} \mathrm{N}$ & $4^{\circ} 40^{\prime} 19 " \mathrm{E}$ & $11^{\circ} 52^{\prime} 71^{1 " N}$ & $3^{\circ} 38^{\prime} 13^{\prime \prime} \mathrm{E}$ & $12^{\circ} 51^{\prime} 21^{\prime \prime N}$ & $4^{\circ} 38^{\prime} 12^{\prime \prime} \mathrm{E}$ & $12^{\circ} 44^{\prime} 16^{\prime \prime} \mathrm{N}$ & $4^{\circ} 30^{\prime} 13 " \mathrm{E}$ & $12^{\circ} 30^{\prime} 37^{\prime \prime} \mathrm{N}$ & $4^{\circ} 19^{\prime} 29^{\prime \prime} \mathrm{E}$ \\
\hline $12^{\circ} 32^{\prime} 30^{\prime \prime} \mathrm{N}$ & $3^{\circ} 49^{\prime} 58^{\prime \prime} \mathrm{E}$ & $11^{\circ} 52^{\prime} 11^{\prime \prime N}$ & $3^{\circ} 37^{\prime} 52^{\prime \prime} \mathrm{E}$ & $12^{\circ} 49^{\prime} 57^{\prime \prime N}$ & $4^{\circ} 37^{\prime} 59 " \mathrm{E}$ & $12^{\circ} 44^{\prime} 50^{\prime \prime N}$ & $4^{\circ} 29^{\prime} 41^{\prime \prime} \mathrm{E}$ & $12^{\circ} 29^{\prime} 19^{\prime \prime N}$ & $4^{\circ} 16^{\prime} 54^{\prime \prime E}$ \\
\hline $12^{\circ} 34^{\prime} 52^{\prime \prime} \mathrm{N}$ & $3^{\circ} 50^{\prime} 111 \mathrm{E}$ & $11^{\circ} 51^{\prime} 58^{\prime \prime N} \mathrm{~N}$ & $3^{\circ} 38^{\prime} 17^{\prime \prime E}$ & $12^{\circ} 48^{\prime} 40^{\prime \prime} \mathrm{N}$ & $4^{\circ} 37^{\prime} 11^{\prime \prime E}$ & $12^{\circ} 45^{\prime} 17^{\prime \prime} \mathrm{N}$ & $4^{\circ} 31^{\prime} 43^{\prime \prime} \mathrm{E}$ & $12^{\circ} 27^{\prime} 90^{\prime \prime} \mathrm{N}$ & $4^{\circ} 15^{\prime} 01 " \mathrm{E}$ \\
\hline $12^{\circ} 33^{\prime} 29^{\prime \prime N}$ & $3^{\circ} 54^{\prime} 71^{\prime \prime} \mathrm{E}$ & $11^{\circ} 50^{\prime} 53^{\prime \prime} \mathrm{N}$ & $3^{\circ} 38^{\prime} 46^{\prime \prime} \mathrm{E}$ & $12^{\circ} 47^{\prime} 23^{\prime \prime N}$ & $4^{\circ} 35^{\prime} 19 " \mathrm{E}$ & $12^{\circ} 45^{\prime} 32^{\prime \prime} \mathrm{N}$ & $4^{\circ} 30^{\prime} 49 " \mathrm{E}$ & $12^{\circ} 23^{\prime} 28^{\prime \prime N}$ & $4^{\circ} 12^{\prime} 11 " \mathrm{E}$ \\
\hline $12^{\circ} 43^{\prime} 53^{\prime \prime} \mathrm{N}$ & $4^{\circ} 18^{\prime} 17^{\prime \prime E}$ & $11^{\circ} 50^{\prime} 39^{\prime \prime} \mathrm{N}$ & $3^{\circ} 38^{\prime} 54^{\prime \prime} \mathrm{E}$ & $12^{\circ} 45^{\prime} 59^{\prime \prime} \mathrm{N}$ & $4^{\circ} 33^{\prime 49} " \mathrm{E}$ & $12^{\circ} 45^{\prime} 49^{\prime \prime} \mathrm{N}$ & $4^{\circ} 29^{\prime} 36 " \mathrm{E}$ & $12^{\circ} 23^{\prime} 21^{\prime \prime} \mathrm{N}$ & $4^{\circ} 11^{\prime 2} 27^{\prime \prime E}$ \\
\hline $12^{\circ} 44^{\prime} 50^{\prime \prime N}$ & $4^{\circ} 17^{\prime} 23^{\prime \prime E}$ & $11^{\circ} 52^{\prime} 20^{\prime \prime} \mathrm{N}$ & $3^{\circ} 39^{\prime} 55^{\prime \prime} \mathrm{E}$ & $12^{\circ} 44^{\prime} 11^{\prime \prime N}$ & $4^{\circ} 39^{\prime} 16^{\prime \prime} \mathrm{E}$ & $12^{\circ} 46^{\prime} 47^{\prime \prime N}$ & $4^{\circ} 29^{\prime} 43^{\prime \prime} \mathrm{E}$ & $12^{\circ} 28^{\prime} 30^{\prime \prime} \mathrm{N}$ & $4^{\circ} 11^{\prime} 46^{\prime \prime} \mathrm{E}$ \\
\hline $12^{\circ} 43^{\prime} 39^{\prime \prime N}$ & $4^{\circ} 70^{\prime} 32^{\prime \prime} \mathrm{E}$ & $11^{\circ} 51^{\prime} 17^{\prime \prime N}$ & $3^{\circ} 40^{\prime} 25^{\prime \prime} \mathrm{E}$ & & & $12^{\circ} 46^{\prime} 11^{\prime \prime N}$ & $4^{\circ} 29^{\prime} 51^{\prime \prime} \mathrm{E}$ & $12^{\circ} 28^{\prime} 24^{\prime \prime} \mathrm{N}$ & $4^{\circ} 11^{\prime} 41^{\prime \prime E}$ \\
\hline $12^{\circ} 43^{\prime} 56^{\prime \prime} \mathrm{N}$ & $4^{\circ} 70^{\prime} 10^{\prime \prime} \mathrm{E}$ & & & & & $12^{\circ} 46^{\prime} 18^{\prime \prime N}$ & $4^{\circ} 25^{\prime} 80^{\prime \prime} \mathrm{E}$ & & \\
\hline $12^{\circ} 40^{\prime} 59^{\prime \prime} \mathrm{N}$ & $4^{\circ} 40^{\prime} 24 " \mathrm{E}$ & & & & & $12^{\circ} 39^{\prime} 27^{\prime \prime N}$ & $4^{\circ} 28^{\prime} 36^{\prime \prime} \mathrm{E}$ & & \\
\hline $12^{\circ} 34^{\prime} 48^{\prime \prime N}$ & $3^{\circ} 53^{\prime} 30^{\prime \prime} \mathrm{E}$ & & & & & & & & \\
\hline
\end{tabular}

Data was obtain using Google Earth Software: US Department of Geographer (2011)

\subsection{Modified Jenny's equation}

The theoretical concept of Jenny's equation (Jenny, 1994): Soil = CL + R + P + O + T [where 'CL' is climate factors, ' $\mathrm{R}$ ' is relief or topography, ' $\mathrm{P}$ ' is parent material, ' $\mathrm{O}$ ' is organism, and ' $\mathrm{T}$ ' is time] was used as a general rule for the assessment and classification of surface soils throughout the period of field survey. However, in order to take consideration of only important physical surface soil factors, the equation was modified by substituting 'CL' with 'SMC' and 'STC' ('SMC' is the surface moisture classes and 'STC' is surface temperature classes), and adding ' $\mathrm{L}$ ' (' $\mathrm{L}$ ' is the land characteristics). Thus, the modified Jenny's equation and its theory mean that the dynamic function of physical surface soils in Sudan Savannah (ss) are functions (f) of surface soil characteristics: temperature/ moisture, parent material, organism, relief and land. The simplification of this statement is given as:

Surface Soil-of-Sudan-Savannah $=\mathrm{f}\left[\left(\mathrm{SMC}+\mathrm{STC}_{\mathrm{ss}}+\mathrm{R}_{\mathrm{kbs}}+\mathrm{P}_{\mathrm{kbs}}+\mathrm{O}_{\mathrm{kbs}}+\mathrm{T}_{\mathrm{kbs}}\right) \mathrm{L}_{\mathrm{kbs}}\right]$ 
In this equation, the surface moisture and temperature characteristics $\left(\mathrm{SMC} / \mathrm{STC}_{\mathrm{kbs}}\right)$ represent the important components of surface soil climates which have acted in the physical formation of old and new surface soil particles in the SS.

The relief/topography $\left(\mathrm{R}_{\mathrm{kbs}}\right)$ that governed the processes of particle transformations from site of origin to another site corresponds to all old/new modified surface soil particles in the SS.

The parent material $\left(\mathrm{P}_{\mathrm{kbs}}\right)$ represents the old and new surface soil particles under which the larger rock fragments have resulted into the formation of surface soils in the SS.

The organisms $\left(\mathrm{O}_{\mathrm{kbs}}\right)$ determine themajor surface soil biotas that have played an important role in the modification of soil particle formation and surface biological manipulations.

The time $\left(\mathrm{T}_{\mathrm{kbs}}\right)$ corresponds to time taken for all soil factors, $\left[\left(\mathrm{SMC}_{\mathrm{STC}} \mathrm{Sbs}_{\mathrm{kbs}}+\mathrm{R}_{\mathrm{kbs}}+\mathrm{P}_{\mathrm{kbs}}+\mathrm{O}_{\mathrm{kbs}}\right) \mathrm{L}_{\mathrm{kbs}}\right]$ to modify and produce the new surface soil particles long time ago, used as independent factors to describe and defined the overall soil forming factors in the SS.

The land characteristics $\left(\mathrm{L}_{\mathrm{kbs}}\right)$ refer to all surface land characteristics, which have produced from the formation of new and old parent particles in the SS.

Overall, the equation infers that the surface soils of the SS is there due to combination of the principal soil forming factors under the entire agricultural surface soils.

Figures 1, 2 and 3showthe examples of the physical components of agricultural surface soils according to their current status in the field. The physical soil bodies shown in these figures were used as field-based materials to classify the parent materials, land characteristics and soil organisms in the SS. The differences of these soil components were evaluated and examined by the VSA. However, where the difficulties occured in this examination, the illuminated magnifying glass was used to view the innert srtuctures of the surface soil bodies, and in some places, the top surface soil cover has been removed to see the true nature of its particles arrangement for accurate classification (Figure 4).
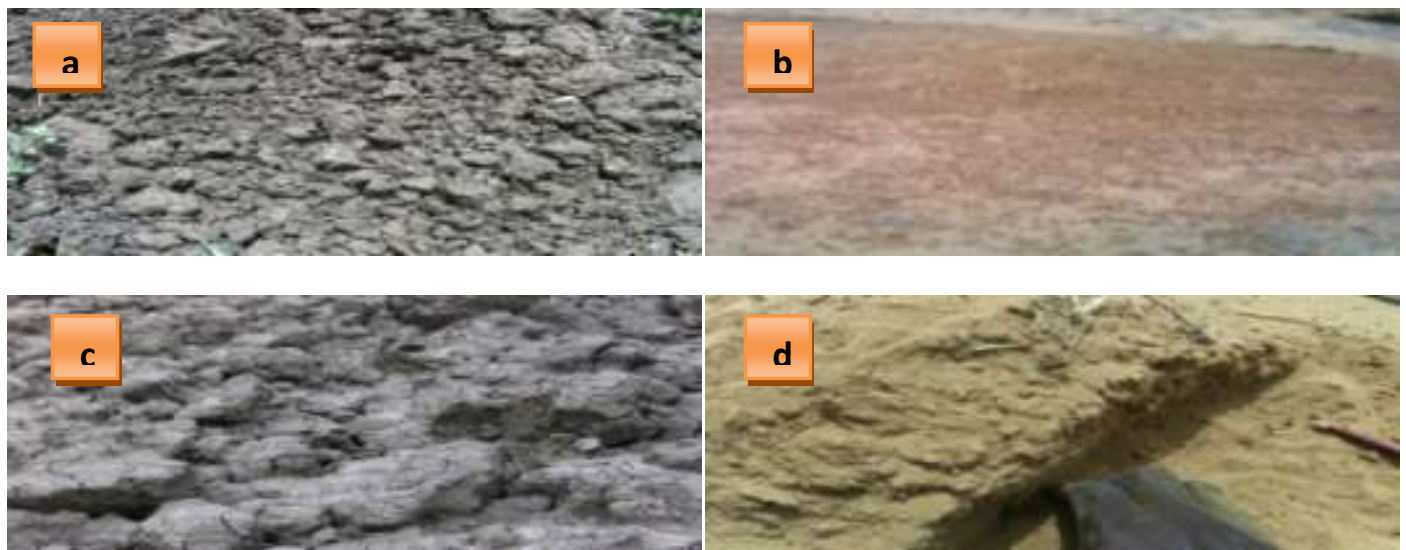

Figure 1: Visual assessment of surface soil parent materials:

(a) alluvial (b) colluvial(c) fluvial and (d) lacustrine
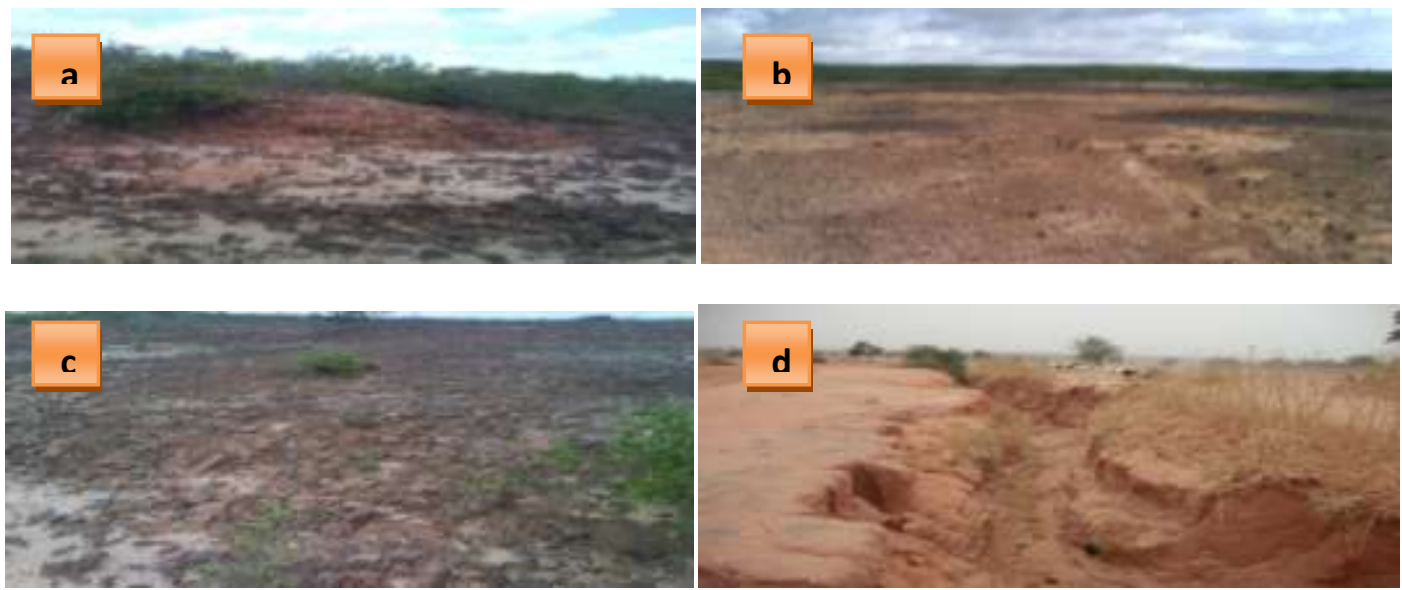

Figure 2: Visual assessment of surface land characteristics:

(a) cirque (b) miscellaneous (c) rock-outcrop and (d) gully 


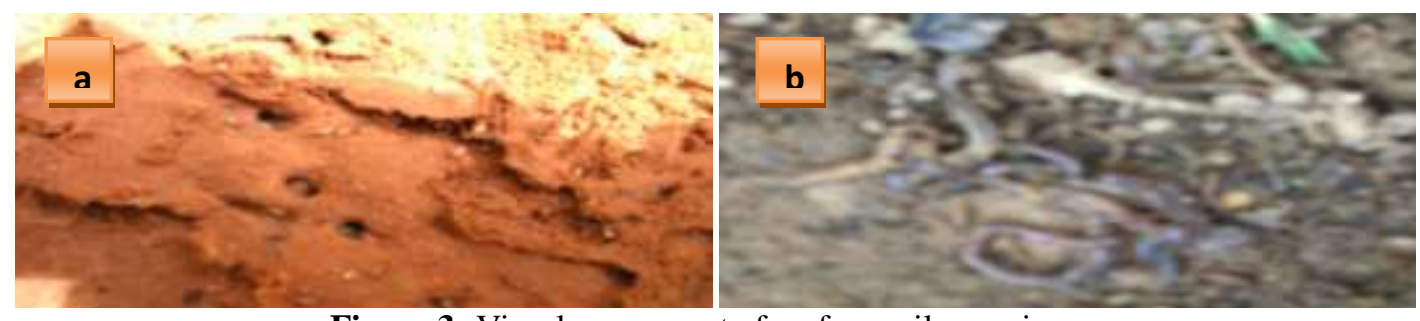

Figure 3: Visual assessment of surface soil organisms:

(a) termites and (b) earthworms

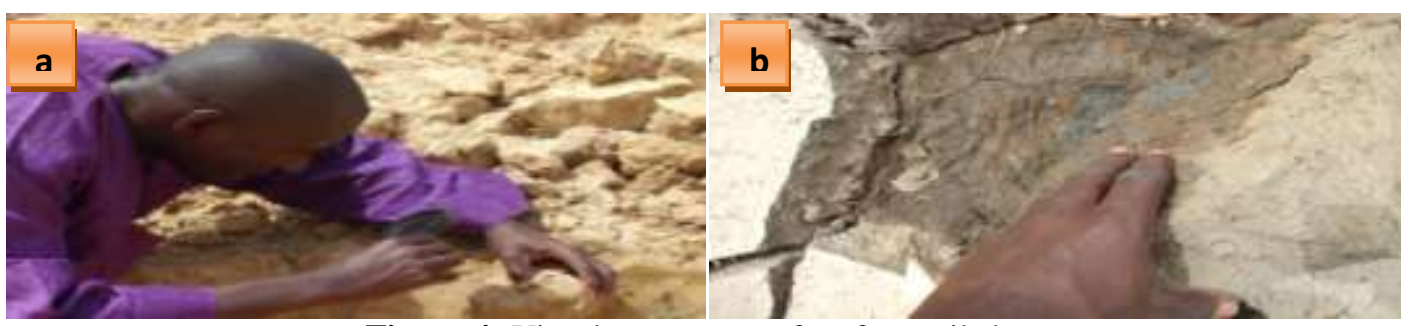

Figure 4: Visual assessment of surface soils by:

(a) illuminated magnifying glass and (b) naked eye after removing the top layer

\section{Results}

The characteristics and classes of surface soils in term of soil factors: moisture, temperature, parent material, topography, organism, and age of soil particles in fadama anddryland areas of the SS are given in Tables 2, 3, 4 and 5 .

Table 2: Surface soil moisture and temperature characteristics

\begin{tabular}{lll}
\hline Moisture class $^{1}$ & Temperature class & Location site \\
\hline Aquic & Cool, cool-warm & Fadama \\
Perudic & Cool, cool-warm & Fadama \\
Udic & Cool & Fadama \\
Ustic & Cool, hot & Fadama \\
Torric & Slightly hot & Dryland \\
Aridic: week, semi + extreme & Hot, warm, very warm & Dryland \\
\hline
\end{tabular}

${ }^{1}$ Moisture characteristics classes (Atkinson, 1993)

Table 2 shows six surface soil moisture characteristics. They are aquic, aridic, perudic, torric, udicandustic. The aridic (sub-types: weak, semi and extremely aridic) and torric are surface moisture characteristics identified in dryland areas. Physically, they are characterised by low to very low moisture characteristics (dryness). The temperature classes of these soil moisture characteristics are hot, warm and slightly hot in the months of April through June, July through October, and December through March.

The terms aquic, perudic, udic and ustic are four surface moisture classes identified under flood plain (fadama) areas. Udic refers to surface areas around rivers and lakes, characterised by sufficient moisture content. Aquic surfaces are characterised by high moisture content around a river side. Perudic is a term used for extremely wetted surface soil characterised by high clay content. The common temperature classes belonging to these four moisture classes are cool and cool-warm. The corresponding location sites of the field survey are givenin the last column of Table 2 .

The surface soil particles under which these moisture and temperature classes were identified, are also classified into residual, deposited, transported, compacted, and addition according to the physical nature of their surface soil formation as derived by climate factors (in form of: water, wind) and human agricultural activities (Table 3).

Residual particles are physically consolidated parent particles, originally formed from the underground mother's rocks through physical, chemical, and biological processes of weathering, derived in place (not transported) by water, wind, and human pressures on land. The alluvial and lacustrine are particles of different kinds, which have dominated large parts of fadama areas in the SS; and they are physically clayed in nature derived only by water. The colluvial, eaolian, and organic parent particles are only found in dryland areas of the region, derived by wind and water.

The alluvial particles are soil particles deposited by water in fadama areas as a result of annual flooding: 'alluvial floodplain clay particles', however, part of these particles that are fairly mixed with sand in 
only few areas of the fadama are also classified as 'alluvial delta sand-clay particles'. Particles that have been physically moved by water during the rainy season and deposited in other areas of dryland are grouped into colluvial rocks particles, colluvial gravelly-sand particles, and colluvial fine-rock fragments; majority of which are well finer sand and silt textured.

Table 3: Major groups of surface soil parent materials and their drivers (factors)

\begin{tabular}{lll}
\hline Group name $^{1}$ & Group $^{2}$ & Major driver \\
\hline Residual: Major Groups & Alluvial & Water \\
& Colluvial & Water/wind \\
& Lacustrine & Wind \\
& Eaolian & Wind \\
& Organic & Human/water \\
& Colluvial rocks particles & Water \\
Deposited: (sub-group) & Colluvial gravelly-sand particles & Water \\
& Colluvial fine-rock fragments & Water \\
& Alluvial floodplain clay particles & Water \\
& Alluvial delta sand-clay particles & Water \\
& & \\
Transported: (sub-group) & Eaolian minor sand-dune particles & Strong-winds \\
& Eaolianaerosolic sand dust particles & Wind \\
& Eaolian loess particles & Wind and windblown \\
& Alluvial sand particles & Water/water \\
& Lacustrine sand particles & Wind/water \\
& Alluvial clay particles & Water \\
& & \\
& Alluvial clay particles & Water \\
& Fluvial clay particles & Water \\
& Lacustrine limestone particles & Water \\
& & \\
& Organic plant debris & Human activities \\
& Organic animal debris & Human activities \\
\hline
\end{tabular}

Classified according to: ${ }^{1}$ Brady and Weil (2004), ${ }^{2} \mathrm{FAO}(2006),{ }^{3}$ Visual Soil Assessment

Furthermore, in some great part of dryland and fadama areas of the SS, water and wind have also transported different soil particles from their original place of formation to another new place of generation. Particles transported by wind in dryland areas are grouped into eaolian minor sand-dune particles and eaolianaerosolic sand-dust particles. The eaolian loess particles are transported by both wind and water. In fadama areas, particle transported by water are also grouped into alluvial clay and sand particles, and lacustrine clay-sand particles.

In fadama and dryland areas, where residual surface soil particles are completely clayed in nature, the term compacted was used to classified the nature of these soil particles. These compacted soil particles are grouped into alluvial clay, fluvial clay, and lacustrine limestone particles. The fluvial clay is soil particles deposited by flooding, and are physically mixed up with other organic particles in fadama. The lacustrine and limestone are particles originated from caliches surface soil environment found in few dryland areas.

Human activities under agricultural intensification and agricultural soil managements have also put other areas of fadama and dryland into organic in nature. Physically, surface soil areas covered by addition of plant and animal manures of different kinds are grouped into organic plant/animal debris.

The overall major classes of parent materials are grouped according to the origin of their formation, from igneous to metamorphic and finally to consolidated and unconsolidated soil particles (Table 4). Physically, the two important soil forming factors that helped in the transformation and translocation of these classes of parent materials is topography. 10 different shapes of topographies were identified, and their names defined the physical structures and shapes of the surface soil conditions as they affected the parent particles. 
Table 4: Surface soil classes of relief, parent materials and organisms

\begin{tabular}{|c|c|c|}
\hline Relief class $^{1}$ & Parent materials $^{2}$ & Land charac. $^{2}$ \\
\hline \multirow[t]{2}{*}{ Back-slope } & Basic metamorphic rocks: sandstones, clay-stone & Miscellaneous \\
\hline & & Rocks-outcrop \\
\hline Bendy & Carbonated sedimentary rocks (consolidated): calcareous & Bad lands \\
\hline Concave & $\begin{array}{l}\text { Clastic sedimentary rocks (consolidated): sand-sand, silt-loam, clay- } \\
\text { loam, loam-silt, sand-stones, rocks, gravels }\end{array}$ & Cirque lands \\
\hline Contour & $\begin{array}{l}\text { Fluvial sedimentary rocks (consolidated): sand, silt, clay, loam: sand- } \\
\text { silt, sand-loam, silt-loam, clay-loam, clay-silt }\end{array}$ & Good lands \\
\hline Convex & Alluvial sedimentary rocks (consolidated): clay: clay-loam & Good lands \\
\hline Deeply & $\begin{array}{l}\text { Lacustrine sedimentary rocks (consolidated): sand, silt, clay: sand- } \\
\text { sand, silt-sand, clay-silt, sand-clay }\end{array}$ & $\begin{array}{l}\text { Blownout-lands } \\
\text { Gullied lands }\end{array}$ \\
\hline Flatly & $\begin{array}{l}\text { Estuarine sedimentary rocks (consolidated): sand, clay: sand-clay, } \\
\text { clay-sand, sand-silt, clay-loam clay-clay }\end{array}$ & Fertile lands \\
\hline Linear-flat & $\begin{array}{l}\text { Colluvial sedimentary rocks (consolidated): deposited particles of } \\
\text { organic materials and sand, clay, loam-silt, }\end{array}$ & Fertile lands \\
\hline Shallow & $\begin{array}{l}\text { Anthropogenic-sedimentary rocks (consolidated): redeposit of natural } \\
\text { materials: sand-clay-silt-loam particles }\end{array}$ & Fertile lands \\
\hline Straight & Unspecified-deposit sedimentary-rocks: loam, sand-silt & Non-fertile land \\
\hline
\end{tabular}

${ }^{1}$ Relief classes USDA-NRCS (2002), ${ }^{2}$ Parent materials classes and Land classes FAO (2006)

The major surface land cover associated with topography and parent materials are classified into badlands, blown-out lands, cirque-lands, fertile-lands, good lands, gullied-lands, miscellaneous and rock outcrops. As name implies, all bad-lands are significantly affected by either rill or gully erosions and not suitable for agriculture, which are contrary to good lands. The blown-out lands are areas characterised by poor surface soil cover, naturally the top soil layer is destroyed. The cirque lands are areas characterised by mixture of sand and rock fragments of which are smaller and bigger in sizes $(1.5-5 \mathrm{~cm}$ : field observation). Fertile land is used to describe the surface soil condition of areas suitable for wide range of agricultural activities (physical observation), no sign of erosion impact, top surface layer is intact. Gully lands are areas damage significantly by water erosion (deep channels $2->10 \mathrm{~m}$ ). The surface land cover characterised by exposures of different rocks fragments (1.0-10cm: field observation) is referred to as rock-outcrop areas,and the miscellaneous are used for land areas characterised by combinations of different soil particles largely sandstones, gravels and smaller fragments of rocks particles, they are difficult to tilt and physically not easy to move away by wind or water.

Table 5: Major group of surface soil biota

\begin{tabular}{|c|c|c|c|c|c|}
\hline $\begin{array}{l}\text { Biota } \\
\text { group }\end{array}$ & Type & Group $^{1}$ & $\begin{array}{ll}\text { Surface } & \text { soil } \\
\text { land area } & \\
\end{array}$ & Population $^{1}$ & $\begin{array}{l}\text { Biophysical surface } \\
\text { activities }\end{array}$ \\
\hline \multirow{4}{*}{$\begin{array}{l}\text { Macro } \\
\text { fauna }\end{array}$} & \multirow[t]{4}{*}{ Termite } & White & Dryland & Millions & \multirow{4}{*}{$\begin{array}{l}\text { Instant breakdown of various } \\
\text { kind organic materials and } \\
\text { mound building of various } \\
\text { sizes. }\end{array}$} \\
\hline & & Red & Dryland & " & \\
\hline & & Milky & Dryland & $"$ & \\
\hline & & Black & Fadama & & \\
\hline \multirow{5}{*}{$\begin{array}{l}\text { Meso } \\
\text { fauna }\end{array}$} & \multirow[t]{3}{*}{ Earthworms } & Dry & Dryland & Thousands & \multirow{3}{*}{$\begin{array}{l}\text { Decompose dead organic } \\
\text { matter and soil colouring. }\end{array}$} \\
\hline & & Fadama & Organic land & Thousands & \\
\hline & & & Alluvial soils & Millions & \\
\hline & \multirow[t]{2}{*}{ Ants } & Black & Dryland & Thousands & \multirow{2}{*}{$\begin{array}{l}\text { Soil particle mixing and } \\
\text { structural transformation. }\end{array}$} \\
\hline & & Brown & Fadama & Thousands & \\
\hline
\end{tabular}

Classification: Field work: 2008 - 2011, ${ }^{1}$ Visual Soil Assessment (based on abundance)

Soil organisms are classified according to the nature of their body appearance, living areas, as well as feeding habit in the field (Table 5). Black termites are found in floodplain areas, whereas white, red and milky termites are found in dry areas. These classes of termites are classified according to their body colours. Ants are grouped into two - black and brown coloured termites. Their biophysical activities differ greatly. The black ants play important role by modifying and breaking up the large variety of soil particles into well-stable structures, whereas the brown ants are larger in size than the black ants, however, there role of soil modification is physically limited to mixing soil particles and making soil holes of different forms. 


\section{Discussion}

Proper assessment and classification of surface soil characteristics are useful linkages to understand the surface soil dynamic functions, which are responsible for great soil development (Atkinson, 1993). However, this assessment/classification will be more realistic if the contextualised Jenny's equation is modified, although its use is limited if the information on substituting classes was not carefully collected in the field (e.g. McRae, 1988). Therefore, the successful data collection and classification processes on surface soil characteristics using the modified Jenny's equation require more time (e.g. 2-3 years) for it to be realistic (e.g. FAO, 2006). In this sense, the information obtained might serve as the basis for soil classification and site evaluation as well as interpretation of the genesis and environmental functions of the soil (FAO, 2006). In the present study, the information was collected from 2008 to 2011. Throughout this period, the factors constituted in the modified Jenny's equation were carefully assessed (Tables: $2,3,4$ ).

Surface soil moisture characteristics are physically functioned as part of soil formation and particles disintegration. This physical function was considered associated by other climate factors such as rainfall, temperature and wind (Yelwa, 2008). The important surface soil moisture characteristics observed are aquic, aridic, torric, ustic, udic and perudic. Aridic is the most common phenomenon found in the great part of dryland areas, more common around Arewa and Dandi. Aquic, udic and ustic are three surface moisture characteristics found around the river side areas of Argungu, Augie and Birnin Kebbi. Perudic surface condition is common phenomena in fadama areas during the rainy season. Basically, these characteristics determine the ability of water to infiltrate/retain in soil under irrigation and drainage conditions (Ritzema, 1994). They also determine the ability of soil particles to move/erode by wind/water under dry and poor vegetation cover (Lal., 1998; Usman, 2007). More importantly, they take part in the regulating and dynamic decomposition of soil organic matter under soil fertility developments (FAO, 2005; Wang et al., 2008), as well as in the geomorphic surface soil changes (Usman et al., 2012).

However, within the dry and flood plain areas of the study area, the flat, levelled and up-and-down undulating topographies formed the dominant physical surface soil structures. The sloping and gently sloping areas terminate at their down-ward edges in concave, convex and flat shapes overlooking the positions of middles, shoulders, summit and end/foot of slopes. None of these positions, or the other shapes prevented the slight impact of surface erosion. Physically, some of these reliefs were affected by sheet, rill and gully channels: some were classified as gullied and bad-land because of soil particle loss. This loss was attributed to initially weakened soil aggregates, i.e. damage to soil structure (Stavi and Lal, 2011) and effects of the biogeochemical cycling of agricultural soils (Quinton et al., 2010).

Various types of surface soil parent materials were also identified (Table 2). It is believe that $10 \%$ to $18 \%$ of the SS's total land area of $10,351 \mathrm{~km}^{2}$ (out of 36, $229 \mathrm{~km}^{2}$ of Kebbi State from 9, 237,773 $\mathrm{km}^{2}$ of Nigerian total land surface) is believed to be occupied by an old crystalline complex of igneous and metamorphic rocks (Usman, 2007). These rocks range in ages from those older than 570 million years (late Precambrian/Ediacaran periods) to those that are younger than 450 million years (Devonian period) (e.g. Ahn, 1970). Physically, $10 \%$ to $13 \%$ of the SS's land surface area is dominated by younger and smaller rock fragments, the majority of which are mixed with sand and loamy sand particles under aquic, aridic, torric, ustic, udic and perudic surface conditions (e.g. Atkinson, 1993). These smaller rock fragments are classified as sandstone soil particles. Some of these particles are from rock outcrops. It is believed that geologically the oldest rocks in the region have further undergone many processes of weathering through natural and man-made soil changes (e.g. Ahn, 1970). These changes have led to the formation of new parent rocks which could have occupied up to $70 \%$ of the total land area. These parent rocks are classified into sedimentary rocks, among which are fluvial, such as pure sand, gravel and clay; alluvial, such as clay and clay loam; lacustrine, such as sand-loam, silt and clay, and estuarine, such as fine sand and clay particles. Soil organisms such as termites, ants, and earthworms might have contributed to the formation and transformation of new and old soil particles in the region. For example, most of the white and milky coloured termites feed on the stalks of many harvested crops. Their activities are considered an important component of soil changes (Arthur et al., 2011). The surfaces characterised by these changes are classified as fertile lands. Land characteristics are characterised by the presence of consolidated and un-consolidated sedimentary parent materials, which would have formed from the weathering of rocks 100 to 10,000 years old (FAO, 2006).

Thus, the overall processes of surface soil formation and breakdown of soil rock's particles in the SS can be completely described as pedogenic (Brady and Weil, 2004): a soil forming processes that comprise four broad basic factors: transformation, translocation, addition, and losses (Table 2). As described (see previous paragraphs), great part of soil parent materials that occupied large portion of dryland and fadama areas in the SS are physically and biologically transformed. Part of this transformation has caused disintegration and alteration of surface soil nature and condition. The major factors behind this alteration include water, wind and human activities (Table 5). Their effect on surface soils was considered deteriorating soil fertility and nutrient status in most agricultural soils (Hartemink, 2006). 
Example, water and wind have been observed to move soil particles from one place to another (Lal, 1998; Zhang et al., 2006; Stavi and Lal, 2011). This movement of soil particles may be positive and or negative. Positively, some areas which are covered by gravel hundreds years ago have now modified and mixed thoroughly with sand/clay, organic particles and rocks fragments. Negatively, water and wind have been both seen as the drivers of surface soil erosion under poor vegetative areas in some part of Arewa, Argungu, Augie, Birnin Kebbi and Dandi. This soil erosion has affectedthe surface soils by deteriorating soil textures and damaging soil structures as noted by Mohammed et al.(2004) and Wall et al.(2006). On the other hand, biological activities are role played by some number of biota groups in the SS. These activities are good example of transformation process of soil formation (Jenny, 1994). Soil biota helped in the decomposition of great materials (plant and animals) in soil and transformed complex inorganic particles to simple organic ones by synthesising organic acid humus and other important product of organic matter in soil (Coleman, 2001; Brady and Weil, 2004).

\section{Conclusion}

The fact that climate, parent materials, relief, organisms and land characteristics are the key factors of soil formation has been known for many years (Jenny, 1994) but with careful visual assessments, the understanding of the physical aspect of this formation has recently improved (FAO, 2008). The present study has shown that the physical components of soil characteristics under agricultural surface soil ecosystem in the SS are influenced by the proper expected functions of moisture and temperature, parent materials, topography, organisms and land characteristics. A clear improvement of understanding environmental aspect of physical components of surface soil, demonstrated the benefits of preliminary field survey using modified Jenny's equation in environmental studies such as soil-crop, climate change, water, forestry, and environmental government policy studies. It has also shown that careful information gathering, using the modified Jenny's equation of soil forming factors under field survey would provide access to qualitative soil information toward proper sustainable soil and environmental managements. Therefore, it leads to the obvious conclusion that an appropriate information gathering through preliminary field survey such as this is the key to efficient understanding of agricultural surface soils.Further studies considering more comprehensive surface soil infomation through field survey are required. This should be fucussing on soil texture, soil structure, soil colour, soil consistency, and soil erosion; as related to soil and crop, soil and water, soil and forest, soil and climate change, and soil and environment as well. The studies will help to provide better understanding of the existing field survey information being produced for the SS of Kebbi State Nigeria.

\section{Acknowledgements}

The study was developed within the activities of Usman PhD programme as undergoing at Natural Resources Institute, the University of Greenwich London, 2013. We hareby acknowledge his brilliant effort and also thank the Kebbi State Government Nigeria for funding hisstudyunder the leadership of Alhaji Saidu Usman Nasamu Dakin-Gari administration.

\section{References}

[1] E. Hartemink, Assessing soil fertility decline in the tropics using soil chemical data. Advances in Agronomy, 89, $2006,1$.

[2] Goudie, The nature of the environment, 4th ed. (Blackwell. Pp. 544, 2001).

[3] Mohammed, F. Al-Quraishi, G. Dao Hu G., and J. Guo Chen, Land Nation plan of action to combat desertification. United National Environmental program (UNEP), 2004.

[4] P. Ritzema, Drainage Principles and Application, 2nd ed. ILRI Publication, (Wageningen, Netherlands. 77-90 pp, 1994).

[5] Arthur E, Cornelis WM, Vermang J and De Rocker E (2011) Amending a loamy sand with three compost types: impact on soil quality. Soil Use and Management, 27, $116-123$.

[6] D. C. Coleman, Soil Biota, Soil Systems, and Processes. Encyclopaedia of Biodiversity, 5,2001, 305-214. Academic Press.

[7] D. H. Yaalon, and B. Yaron, Framework for man-made soil changes - and outline of metapedogenesis. Soil Science, 102-4, 1966, 272-277.

[8] E. A. Fitzpatrick, Soils: Their Formation, Classification and Distribution, (Printed in Great Britain at the Printman press, Longman Group Ltd. London. Pp 50-51 \& 138-140, 1980).

[9] EU, Visual Soil Assessment: Field guide. Houskova, B. and Montanerella, L. (Eds.) (European Union, 2010).

[10] FAO (2006) Guidelines for Soil Descriptions 5th ed. Food and Agricultural Organization of United Nation, Rome, Italy.

[11] FAO, The importance of soil organic matter: key to drought-resistant soil and sustained food production. FAO Soils Bulletin, No. 80. Food and Agricultural Organization of United Nation, Rome, Italy. 11-47 \& 65pp, 2005.

[12] FAO, Visual Soil Assessment - Field Guide. FAO, Rome, Italy, 2008.

[13] G. R. S. Certini, Soils: Basic Concept and Future Challenges, (Cambridge University Press, 32pp, 2006).

[14] G. W. Olson, Soils and the environment: A guide to soil surveys and their applications, (Dowden and Culver Book and Chapman and Hall, New York and London, 1981).

[15] G. Wall, C. S. Baldwin, and I. J. Shelton, Soil erosion causes and effects, (Ontario Ministry of Agriculture, Food and Rural Affairs. Queen's printer for Ontario, Canada. Pp3-6, 2006).

[16] H. J. S. Finch, A. J. L. Wiseman, A. M. Samuel, and G. P. F. Lane, Lockhart and Wiseman's Crop Husbandry: Including Grassland, (Woodhead, pp 528, 2002).

[17] H. Jenny, Factors of Soil Formation: A system of quantitative pedology, 6th ed, (Dover publications Inc, New York, 1994). 
[18] Stavi, and R. Lal R., Loss of soil resources from water-eroded versus uneroded cropland sites under simulated rainfall. Soil Use and Management, 27,2011, $69-76$.

[19] IPCC, Summary for policymakers. In: Climate Change 2007: The physical Science Basis. Contribution of working group I to the fourth assessment report of the intergovernmental panel on climate change. Solomon and co-workers (Eds), (Cambridge University Press, Cambridge, UK and New York, USA, 2007)

[20] J. Atkinson, An Introduction to the mechanics of soils and foundation, (McGRAW-HILL Book Company Europe, Berkshire, SL6 2QL, England, 1993).

[21] J. C. Phillip, Urban Soils in Landscape Design, (John Wiley and Sons. 416pp, 11992).

[22] J. N. Quinton, G. Govers, K. Van oost, and R. D. Barrdgett, The impact of agricultural soil erosion on biogeochemical cycling, Nature Geoscience, 3, 2010, $311-376$.

[23] J. W. Harden, Soil development on stable landforms and implications for landscape studies, (Soil and Landscape Centre Pp 8-11, 1990).

[24] K. A. Lemke, M. E. Ritter, and N. Heywood, The physical environment to physical geography: Lab Manual. (UWSP, 2003).

[25] K. Zhang, X. Li, W. Zhou, D. Zhang, Z. Yu , Land resource degradation in China: Analysis of status, trends and strategy. International Journal of Sustainable Development and World Ecology, 13, (5), 2006, 397-408(12).

[26] KARDA, Soil and Environmental Information in Kebbi State (Kebbi Agricultural and Rural Development Authority (KARDA), Kebbi State Nigeria, 2009).

[27] L. D. McFadden, and P. L. K. Kneupfer, Soil geomorphology: The linkage of pedology and superficial process, Geomorphology, vol. 3, 1990, 197-205.

[28] M. C. Wang, Y. H. Liu,Q. Wang, M. Gong, X. M. Hua, Y. J. Pang, S. Hu, and Y. H. Yang, Impacts of methamidophos on the biochemical, catabolic and genetic characteristics of soil microbial communities. Soil Biology and Biochemistry, 40(3), 2008, 778788.

[29] N. A. Krasil'nikov, Soil micro-organism and higher plants. Academy of science of the USSR, Moscow, (National Science Foundation, Washington DC and Department of Agriculture, USA. Israel programme for scientific translation. P1, 1961).

[30] N. C. Brady, and R. R. Weil, Elements of the nature and properties of soil. 2nd ed. (Person Education Ltd. pp. 9-24, 2004).

[31] NRCS, Soil Quality Glossaries: The Soil Quality Thunder-book, (Natural Resource Conservation Service, USDA, 2004).

[32] O. W. Bidwell, and F. D. Hole, Man as a factor of soil formation, Soil Science, 99, 1965 65-72.

[33] P. M. Ahn, West African Soils (Oxford University Press. 231pp, 1970)

[34] R. Amundsen, and H. Jenny, The place of humans in the state factor theory of ecosystems and their soils. Soil Science, 151-1, 1991, 99-109.

[35] R. Boulding, and S. G. Jon, Practical Handbook of Soil: Vadosezone and Ground-water, (CRC Press, Pp. 16-18, 2003).

[36] R. Dudal, F. Nactergaele, and M. Purnell, M. (2002) The human factor of soil formation. Symposium 18, vol. II, paper 93. Transactions 17th World Congress of Soil Science Bagkok, 2002.

[37] R. Dudal, The Six Factor of Soil Formation. A paper presented at the International Conference on Soil Classification 2004, Petrozavodsk, Russia, 3-5 August. (Institute for Land and Water Management, b-3000 Leuven, Belgium, 2004).

[38] R. Lal, Soil erosion impact on agronomic productivity and environment quality. Crit. Rev. Plant Sci. 17, $1998,319-464$.

[39] R. Sund, B. Tillery, and L. Trowbridge, Elementary science discovery lessons. (Earth science, Boston, M. A. Allyn and Bacon Inc, 1973).

[40] R. W. Arnold, I. Szabolcs, and V. O. Targulian, (Eds.), Global Soil Change, Report of IISA-ISSS-UNEP Task Force, Int. Inst. for Applied Syst. Anly. Laxenburg, Austria, 1990).

[41] S. A. Yalwa, Broad scale vegetation change assessment across Nigeria from coarse special and high temporal resolution AVHRR Data. (CuvillierVerlag, Gottingen Nonnenoteg, Gottinen. Pp 60 - 61, 2008).

[42] S. Usman, P. J. A. Burt, and S. S. Noma, Characteristics of the surface soil ecosystem: linkage to understanding soil dynamic function. In: Proc. of the SAC and SEPA Biennial Confr. on Agriculture and the Environment IX, Valuing Ecosystems: Policy, Economic and Management Interactions (2012) Crighton, K. (ed.), 3th - 4th April 2012, Edinburgh. Pp. 298 - 304.

[43] S. Usman, Sustainable soil management of the dryland soils of northern Nigeria, (GRIN Publishing GmbH, Germany ISBN (Book): 978-3-640-92136-2, 2007).

[44] S. Usman, Understanding Soil: properties and environment under agricultural condition, (PublishAmerica, USA, 2012).

[45] Soil Survey Staff (1999) Soil taxonomy: a basic system of soil classification for making and interpreting soil survey 2nd ed. Agricultural Handbook 436. (Natural Resource Conservation Service USDA, Washington, US Government Printing Office. Pp. 869, 1999).

[46] Soil Survey Staff, Keys to Soil Taxonomy. 11th edn. (USDA-NRCS, Washington DC, 2010).

[47] US Department of State Geographer, Google Earth: Map-Link/Tale Atlas. Europa Technologies, USA, 2011.

[48] USDA-NRCS, Field Book for Describing and Sampling Soils, Version 2.0. (National Natural Resource Conservation Service and USDA. Soil Survey Centre, 2002). 